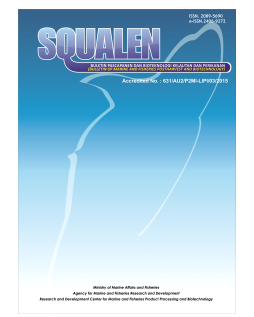

\title{
CHEMICAL PRETREATMENT AND ENZYMATIC SACCHARIFICATION OF SEAWEED SOLID WASTES
}

\author{
Pujoyuwono Martosuyono*, Andi Hakim, and Yusro Nuri Fawzya \\ Research and Development Center for Marine and Fisheries Product Processing and Biotehnology, \\ Jalan KS. Tubun Petamburan VI, Slipi, Central Jakarta 10260, Indonesia \\ Article history: \\ Received: 20 June 2015; Revised:13 July 2015; Accepted: 20 July 2015
}

\begin{abstract}
The technical feasibility of seaweed waste utilization as a resource of renewable energy was investigated in this paper. The production of fermentable sugars from seaweed waste was studied by dilute sulfuric acid and sodium hydroxide pretreatment and further enzymatic hydrolysis. Pretreatment was conducted by using 1.0 and $2.0 \%$ dilute sulfuric acid $\mathrm{w} / \mathrm{v}$ and 4 and $5 \%$ sodium hydroxide $\mathrm{w} / \mathrm{v}$ for $30 \mathrm{~min}$ at $121{ }^{\circ} \mathrm{C}$. Pretreated seaweed wastes were analyzed by X-Ray Diffraction (XRD) to examine the crystallinity index of the cellulose and observed using Scanning Electron Microscopy (SEM) to examine the changes in structure of cellulose fiber. Saccharification of pretreated seaweed waste was carried out using crude cellulase enzyme provided by Pulp and Paper Research Center in Bandung. Saccharification was done in shake flask with $20 \%$ of substrate in citrate phosphate buffer at $30{ }^{\circ} \mathrm{C}$ and $50{ }^{\circ} \mathrm{C}$, agitation of $150 \mathrm{rpm}$ in shaking incubator for $48 \mathrm{~h}$. Samples were collected at 2, 6, 12, 24 and $48 \mathrm{~h}$ for further analysis. Enzyme concentrations were varied between $10-50 \mathrm{U} / \mathrm{g}$ dry samples. The results showed that dilute acid and base pretreatment of seaweed solid waste can be used to improve the digestibility of seaweed waste. It successfully acted by reducing the lignin content and degrading the structure of cellulose from crystalline into amorphous form which is more susceptible to the enzyme action. The optimum pretreatment condition was shown by $4 \% \mathrm{NaOH}$ at $121{ }^{\circ} \mathrm{C}$ for $30 \mathrm{~min}$, producing the most fermentable sugar concentration. Sugar concentration produced by saccharification was optimum at $50{ }^{\circ} \mathrm{C}$, enzyme concentration of $50 \mathrm{U} / \mathrm{g}$ sample for $24 \mathrm{~h}$ base pretreatment. The results of the experiment were expected to contribute in the process development of bioconversion of lignocellulosic materials into renewable energy sources.
\end{abstract}

Keywords: acid hydrolysis, base hidrolysis, crude cellulase, solid seaweed waste

\section{Introduction}

Energy security, increase of oil price, resources depletion and climate change are some of the greatest challenges facing our societies in incoming decades. It has been long expected that renewable energy sources from biomass can, at least partially mitigate these problems and create more sustainable and balanced economies. Energy production from biomass has emerged as one of the more attractive and promising alternatives to fossil fuels. Indonesian Government was launching a Regulation of the Government of the Republic Indonesia concerning the National Energy Policy which targeting the role of new energy and renewable energy sources is at least $23 \%$ in year 2025 and $31 \%$ in 2050. It is clear that direction of national energy policy in Indonesia is to intensify the exploration of new energy sources other than fossil fuel to maintain the energy security.

To date three generations of energy crops (and biofuels) have been developed. Ethanol produced from materials containing sugar and starch is regarded as the first generation of bioethanol. However, many problems including food security and land substitution are brought up with the increasing demand for the first generation of bioethanol. The second generation of bioethanol uses cellulosic wastes as feedstock because of its relative abundance and low cost. It was concluded that the use of by products might ease the pressure on land area requirement considerably and it should not be neglected in assessing the impacts of biofuel provision worldwide (Özdemir et al., 2009).

${ }^{*}$ Corresponding author.

E-mail: pujo_yuwono@yahoo.com.au 
The limitation of first and second generation of ethanol production directing our attention toward seaweeds, a diverse group of autotrophic organisms, as an alternative substrate for the bioethanol production known as third generation of bioethanol production. Third generation biofuel feedstock, macroalgae can have an edge over the previous two. These marine organisms show the prospect of high biomass yields and have the potential to be cultivated in an containment off shore. Moreover, algal feedstocks have several advantages, which include high area productivity, no competition with conventional agriculture for land, utilization of different water sources (e.g.,seawater, brackish water and waste water), recycling of carbon dioxide, and compatibility with integrated production of fuels and co-products within biorefineries (Sahoo et al., 2012). Those features along with successful methods for large-scale algae cultivation and processing can make third generation feedstock superior.

The use of enzymatic hydrolysis to convert cellulose and hemicellulose into fermentable sugars has been studied extensively, in view of its great potential for application in improving economic feasibility of bioethanol production. Wu et al. (2014) used sequential acid-enzymatic hydrolysis on Gracillaria to produce ethanol by free and immobilized yeast. The ethanol yield was $0.48 \mathrm{~g} / \mathrm{g}$ sugar produced by hydrolysis. Other research using cellulase enzyme for saccharification process was reported by Kumar et al. (2013) on agar waste of Gracillaria with ethanol yield $0.43 \mathrm{~g} / \mathrm{g}$ sugar.

Macroalgae are gaining more attention as an alternative renewable source of biomass for the production of bioethanol. Many researches have been conducted on the utilization of the marine algae biomass as bioethanol feedstock. Different macroalgae groups, such as Laminaria (Adams et al., 2009; Ge et al., 2011; Horn et al., 2000; Kim et al., 2011), Gelidium amansii (Yoon et al., 2010), and Kappaphycus alvarezii (Meinita et al., 2011), have been considered as potential sources for bioconversion to ethanol. The feasibility of producing bioethanol from the brown seaweed, Sargassum sagamianum was also investigated by Yeon et al. (2011). Some researches on the utilization of seaweed waste as source of bioethanol and chemical feedstocks were reported. Bioconversion of carrageenan waste treated by peracetic acid-ionic liquid into bioethanol was reported by Uju et al. (2013).

The aim of this work is to study the effects of dilute acid and base pretreatment on the saccharification process of seaweed solid waste as a potential source of fermentable sugar for conversion to bioethanol. In this study, seaweed wastes as a by-product in agar industry containing high cellulose and low hemicellulose and lignin content was used. The optimum conditions of pretreatment to increase the bioconversion rate of waste into fermentable sugars were studied in this work.

\section{Material and Methods}

\subsection{Seaweed Solid Waste}

The raw material, seaweed solid waste was collected from small scale agar industry in Pameungpeuk, District of Garut, West Java. The type of seaweed was identified as Gracillaria sp. in which sheet agar was the main product. The solid agar waste was milled and screened through 20-80 mesh and sun dried prior to pretreatment. The milled raw material was stored in desiccators at room temperature until being further processed. The experiments carried out in this paper include pretreatment with dilute acid and base, determination of cellulose and lignin content, characterization of pretreated waste by X-Ray Diffraction (XRD) and Scanning Electron Microscopy (SEM), followed by enzymatic saccharification by crude cellulase enzyme at 30 and $50^{\circ} \mathrm{C}$ at various enzyme concentration. All experiments were conducted in triplicate otherwise specifically stated.

\subsection{Dilute Acid and Base Pretreatment}

The dilute acid pretreatment of solid seaweed waste was optimized at $121^{\circ} \mathrm{C}$ for different sulfuric acid concentrations ( 1 and $2 \%, w / v$ ) and concentrations of $\mathrm{NaOH}$ were 4 and $5 \%(\mathrm{w} / \mathrm{v})$ for $30 \mathrm{~min}$. The ratio of waste: acid/base was $1: 5$ (1 g of sample added by 5 $\mathrm{ml}$ of acid/base). After pretreatment, the acid insoluble residue was collected by filtration and subsequently washed thoroughly with hot water, weighed and analyzed for cellulose and lignin content.

\subsection{Lignin and Cellulose Contentof Seaweed Waste}

Lignin and cellulose content of seaweed solid waste were analysed in Laboratory of Pulp and Paper Research Center, Ministry of Industrial Affairs. The content of lignin and cellulose were determined as follows: $0.7 \mathrm{~g}$ of air dried samples, ground $(0.5 \mathrm{~mm})$ were boiled with $5 \mathrm{ml}$ of $72 \% \mathrm{w} / \mathrm{w} \mathrm{H}_{2} \mathrm{SO}_{4}$ solution for $4.5 \mathrm{~h}$ in order to hydrolyse the cellulose and hemicellulose. The suspension remaining after the above treatment was filtered through a crucible and the solid residue dried at $105^{\circ} \mathrm{C}$ for $24 \mathrm{~h}$ and weighed (W1). The residue was then transferred to a preweighed dry porcelain crucible and heated at $600^{\circ} \mathrm{C}$ for $5 \mathrm{~h}$. After cooling down, it was weighed (W2) and ash content (\%) was determined. Acid insoluble lignin 
was then calculated by the difference (W1-W2). The filtrate from the $\mathrm{H}_{2} \mathrm{SO}_{4}$ treatment that contained the sugars released from cellulose and hemicellulose was thoroughly stirred and homogenized. Glucose (C1) and reducing sugar (C2) concentrations in the filtrate were determined by the DNS method(Miller, 1959). Following these measurements, the cellulose content in the starting material was calculated using the following equation:

$\% \mathrm{w} / \mathrm{w}$ cellulose content $=(0.9 / 0.96) \times \mathrm{C} 1 \times(\mathrm{V} / \mathrm{M}) \times \alpha \times 100$

Where 0.9 is the coefficient that results from the molecular weight ratio of the polymer and the monomer hexose. The saccharification yield was taken as 0.96 , $\mathrm{C} 1$ as the glucose concentration $(\mathrm{g} / \mathrm{L}), \mathrm{V}$ the total volume of sugar solution( $(\mathrm{L}), \mathrm{M}$ the dry weight of the algal biomass sample $(\mathrm{g})$ and $\alpha$ the dilution of the sample.

\subsection{Characterization of Pretreated Solid Agar Wastes}

Characteristics of pretreated solid agar waste were analyzed by X-ray diffraction (XRD) analysis to examine the crystallinity index of cellulose. XRD analysis was carried out in material laboratory, Department of Physics, Bogor Agricultural University. To determine changes in cellulose fiber structure, samples were analyzed using Scanning Electron Microscopy (SEM) in Agricultural Postharvest Laboratory, Ministry of Agriculture. All samples were analyzed using 5.000 times of magnification.

\subsection{Saccharification of Pretreated Seaweed Waste}

A crude cellulase enzyme from Pulp and Paper Research Center, Ministry of Industrial Affairs in Bandung was used in this experiment for saccharification procedure. The saccharifcation process was conducted at the concentration of 10 ,
$20,30,40$ and $50 \mathrm{U} / \mathrm{g}$ substrate at 30 and $50^{\circ} \mathrm{C}$ for 0 , $6,12,24$, and $48 \mathrm{~h}$. Sugar concentration was measured by reacting the saccharification product with 3,5-dinitrosalycilic acid (DNS) and read the absorbance at $575 \mathrm{~nm}$.

\section{Results and Discussion}

\subsection{Characteristics of Solid Seaweed Waste}

Characteristics of agar waste used in this experiments were shown in the Table 1 . The content of cellulose, hemicelluloses, lignin, and other major components were compared to the other materials have been used as source of lignocellulosic materials for bioethanol production. The content of cellulose and hemicelluloses of agar processing waste were relatively low compared to other sources.

High content of hemicellulose and the presence of lignin in terrestrial biomass, usually pretreatment was performed under extreme conditions: high temperature $\left(165-210^{\circ} \mathrm{C}\right)$, high concentration of chemical solvents or long time (4 weeks). It was reported that the maximum cellulose recovery of wheat straw was $92 \%$ under hydrothermal pretreatment conditions at $195^{\circ} \mathrm{C}$ for $6-12 \mathrm{~min}$ followed by enzymatic hydrolysis (Petersen et al., 2009). The dilute acid pretreatment usually needs high temperature $\left(160-220^{\circ} \mathrm{C}\right)$ fitted with lower acid dose $(0-2.0 \%)$ for the terrestrial biomass. In contrast, the temperature can be lower $\left(121^{\circ} \mathrm{C}\right)$ when fitted with higher acid levels. In other studies the maximum saccharification value $(36.3 \mathrm{~g}$ sugar/100 g raw material) was obtained when olive tree biomass was pretreated at $180{ }^{\circ} \mathrm{C}$ with $1.0 \%$ sulfuric acid, representing $75 \%$ of all sugars in the raw material (Cara et al., 2008) Even though pretreatments above all are effective and the high conversion of cellulose from terrestrial plants was obtained, the pretreatment for reduction in the

Table 1. Composition of raw material commonly used as source of bioethanol production

\begin{tabular}{lccccccc}
\hline Composition & $\begin{array}{c}\text { Agar Proc. Sargassum } \\
\text { Waste (\%) }\end{array}$ & $\begin{array}{c}\text { Alginat } \\
\text { sp (\%) }\end{array}$ & $\begin{array}{c}\text { Proc. Waste } \\
\text { (\%) }\end{array}$ & $\begin{array}{c}\text { Gracilaria } \\
\text { sp (\%) }\end{array}$ & $\begin{array}{c}\text { Agar Sari } \\
(\%)\end{array}$ & $\begin{array}{c}\text { Hardwood } \\
(\%)\end{array}$ & $\begin{array}{c}\text { Cornstalks } \\
(\%)\end{array}$ \\
\hline Cellulose & $\mathbf{3 3 . 7}$ & 44.6 & 41 & 51.6 & 28 & 45 & $39-47$ \\
Lignin & $\mathbf{4}$ & 21 & 20 & 12 & 2 & 20 & $3-5$ \\
Hemicellulose & $\mathbf{1 . 1}$ & 1.4 & 4.8 & 2 & 10 & 30 & $26-31$ \\
Agar & & & & & 37 & - & \\
Water & $\mathbf{3 . 8}$ & 10 & 16 & 11.8 & 13 & 5 & \\
\hline
\end{tabular}

Source: ${ }^{1}$ Uju et al. (2013); ${ }^{2}$ Wu et al. (2014) 
crystallinity of cellulose, removal of lignin and hemicellulose postponed treatment time, increased energy consumption and production cost.

\subsection{Characteristics of the Waste after Pretreatment}

The result of acid and base pretreatment on seaweed solid waste was shown in Figure 1. The cellulose content of treated seaweed waste increases in line with concentration of acid. However higher base concentration reduces the content of cellulose. In contrast, lignin content decreased as the concentration of acid and base increased. The effectiveness of delignification was higher by $\mathrm{NaOH}$ treatment compared to $\mathrm{H}_{2} \mathrm{SO}_{4}$. More than $70 \%$ of lignin content was removed by basic treatment while acid treatment only remove less than $25 \%$ of lignin.

The content of cellulose of seaweed solid waste after pretreatment using $\mathrm{H}_{2} \mathrm{SO}_{4}$ was increased into 33 and $44 \%$ from the initial concentration of $20 \%$. However, by $\mathrm{NaOH}$ treatment the cellulose content were increased to more than $80 \%$. It means that basic pretreatment effectively removed any unwanted

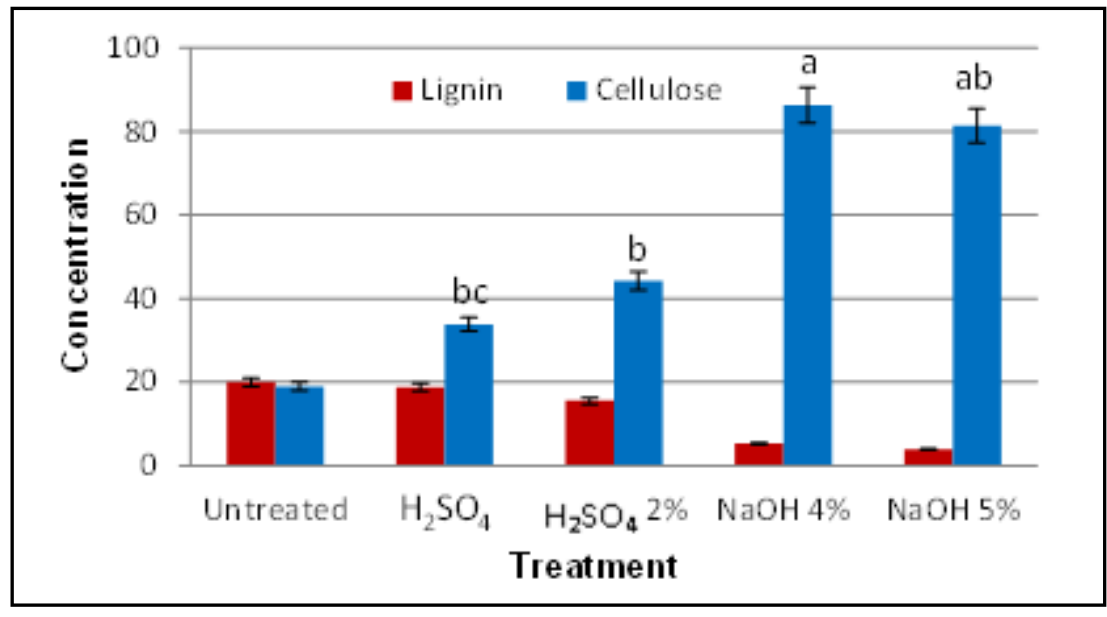

Figure 1. The cellulose and lignin content of untreated and pretreated seaweed waste by acid and base.

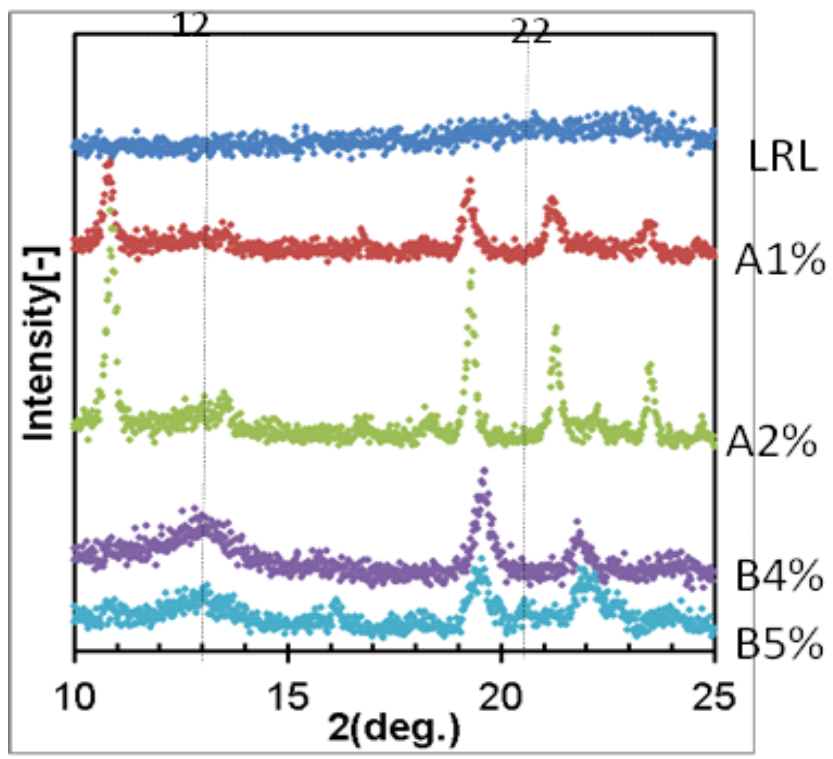

Figure 2. XRD analysis of untreated, acid and base pretreated solid agar wastes.

$\mathrm{LRL}=$ untreated solid agar waste

A $1 \%=$ solid agar waste treated by $1 \% \mathrm{H}_{2} \mathrm{SO}_{4}$

$\mathrm{A} 2 \%=$ solid agar waste treated by $2 \% \mathrm{H}_{2} \mathrm{SO}_{4}$

$\mathrm{B} 4 \%=$ solid agar waste treated by $4 \% \mathrm{NaOH}$

$\mathrm{B} 5 \%=$ solid agar waste treated by $5 \% \mathrm{NaOH}$ 
A

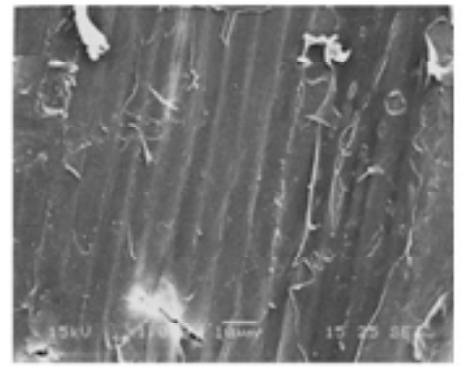

$\mathrm{B}$

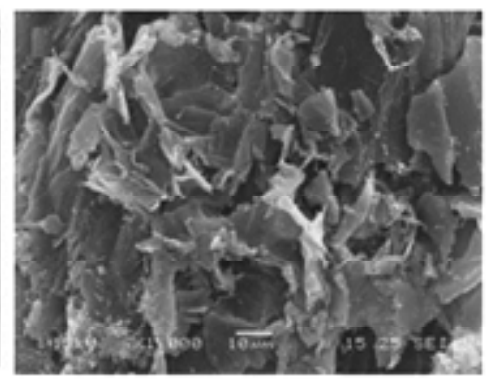

C

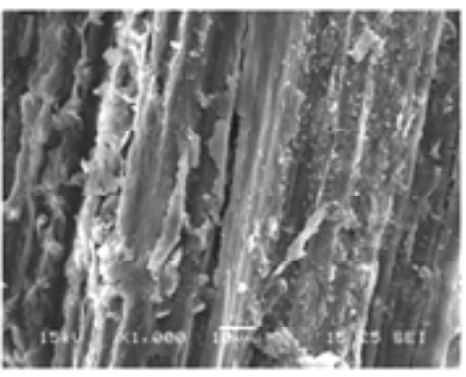

Figure 3. Scanning Electron Microscopy of untreated and acid pretreated solid agar waste.

$\mathrm{A}=$ untreated agar waste; $\mathrm{B}=$ agar waste treated with $1 \% \mathrm{H}_{2} \mathrm{SO}_{4} ; \mathrm{C}=$ agar waste treated with $2 \% \mathrm{H}_{2} \mathrm{SO}_{4}$

A

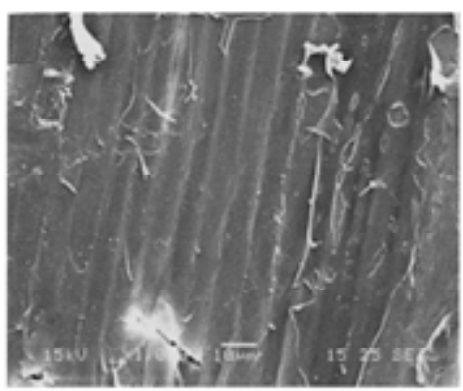

B

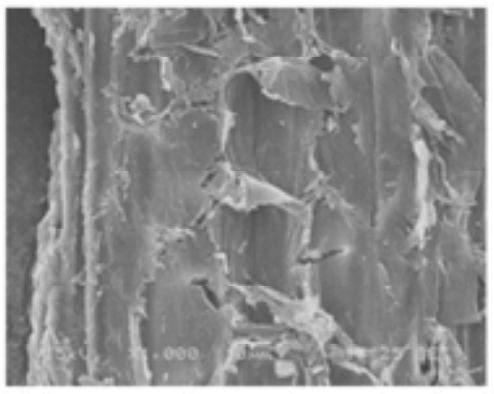

C

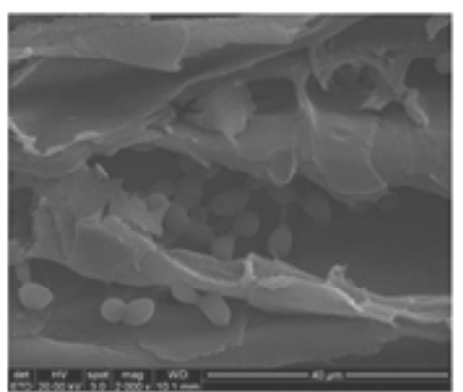

Figure 4. Scanning Electron Microscopy of untreated and base pretreated solid agar waste.

$A=$ untreated agar waste; $\mathrm{B}=$ agar waste treated with $4 \% \mathrm{NaOH} ; \mathrm{C}=$ agar waste treated with $5 \% \mathrm{NaOH}$

content other than cellulose. Based on statistical analysis (ANOVA), cellulose content of waste pretreated by $\mathrm{NaOH}$ was significantly different than those pretreated by sulfuric acid at confidence level of $95 \%$.

Pretreatment of solid agar waste was carried out to make the cellulose more susceptible to the cellulase enzyme action by opening the structure of crystalline fiber into the amorphous form. Based on the difractogram, it can be seen that agar waste has crystalline cellulose as dominant fraction, indicating that phosphate-polysaccahrida was dominant (no peaks) and cellulose as amorphous fraction is in small part. Treatment with acid and basic increased the amorphous fraction and concentrated the cellulose, as shown by small peak at $12^{\circ}$. Seaweed waste is presumed to contain impurities that comes from the agar extraction process.

SEM (scanning electron microscopy) analysis of pretreated seaweed waste before enzymatic saccharification revealed ultra structural changes in seaweed solid wastes after pretreatment. The images were magnified by a factor of 5000 . As shown in Figures 3 and 4 , the surface of the untreated agar waste was continuous and smooth and coated with crystals. After treatment with acid and base (Figures 3 and 4 B,C), it became more rugged and loosed and it seems that more internal structures were exposed. Based on this result, it is evident that acid and base pretreatment alter the structure of the agar waste and may probably increase the accessible surface area for enzymatic hydrolysis. This finding confirmed the disintegration of the samples cellulosic structure due to the acid and base pretreatments of solid agar waste which producing more fermentable sugars than the untreated sample.

\subsection{Saccharification of Seaweed Wastes}

The conversion of solid waste to produce fermentable sugars was carried out by enzymatic saccharification at two different temperatures, varied enzyme concentration and length of the process. Untreated and pretreated solid seaweed wastes were used to show the effect of acid and base treatment on the digestibility of samples.

\subsubsection{Saccharification at $30^{\circ} \mathrm{C}$}

Saccharification of untreated seaweed waste at varied enzyme concentration and length of the process was shown in Figure 5. The concentration of fermentable sugars of untreated seaweed waste after saccharification are very low (less than $500 \mathrm{mg} / \mathrm{L}$ ). This is caused as the lignin content in the sample is remaining high and the structure of cellulose of 
seaweed waste is mostly in crystalline form which is unsusceptible to the enzyme work.

Acid and base-pretreated seaweed waste treated with the same concentration of cellulase enzyme produced more fermentable sugars as shown in Figures 6 and 7. Pretreatment of seaweed solid waste was carried out at $121^{\circ} \mathrm{C}$ for 30,60 and 90 minutes in 1 and $2 \%$ of sulfuric acid. Pretreatment with sulfuric acid gave a good result in saccharification as shown by the concentration of reducing sugar. A different length of pretreatment did not affect significant results. The concentration of reducing sugar at 30 minutes
(A2), 60 minutes (A6), and 90 minutes (A10) at $1 \%$ $\mathrm{H}_{2} \mathrm{SO}_{4}$ giving the highest concentration of reducing sugar with insignificant differences. Based on this data, the best pretreatment of seaweed solid waste was shown at $121{ }^{\circ} \mathrm{C}$, for 30 minutes and $4 \%$ of sodium hydroxide.

\subsubsection{Saccharification at $50^{\circ} \mathrm{C}$}

The concentration of fermentable sugars of untreated seaweed waste after saccharification at $50^{\circ} \mathrm{C}$ is higher than $30^{\circ} \mathrm{C}$ which as high as $2,200 \mathrm{mg} /$ $\mathrm{L}$ (Figure 8) compared to less than $500 \mathrm{mg} / \mathrm{L}$ at $30^{\circ} \mathrm{C}$

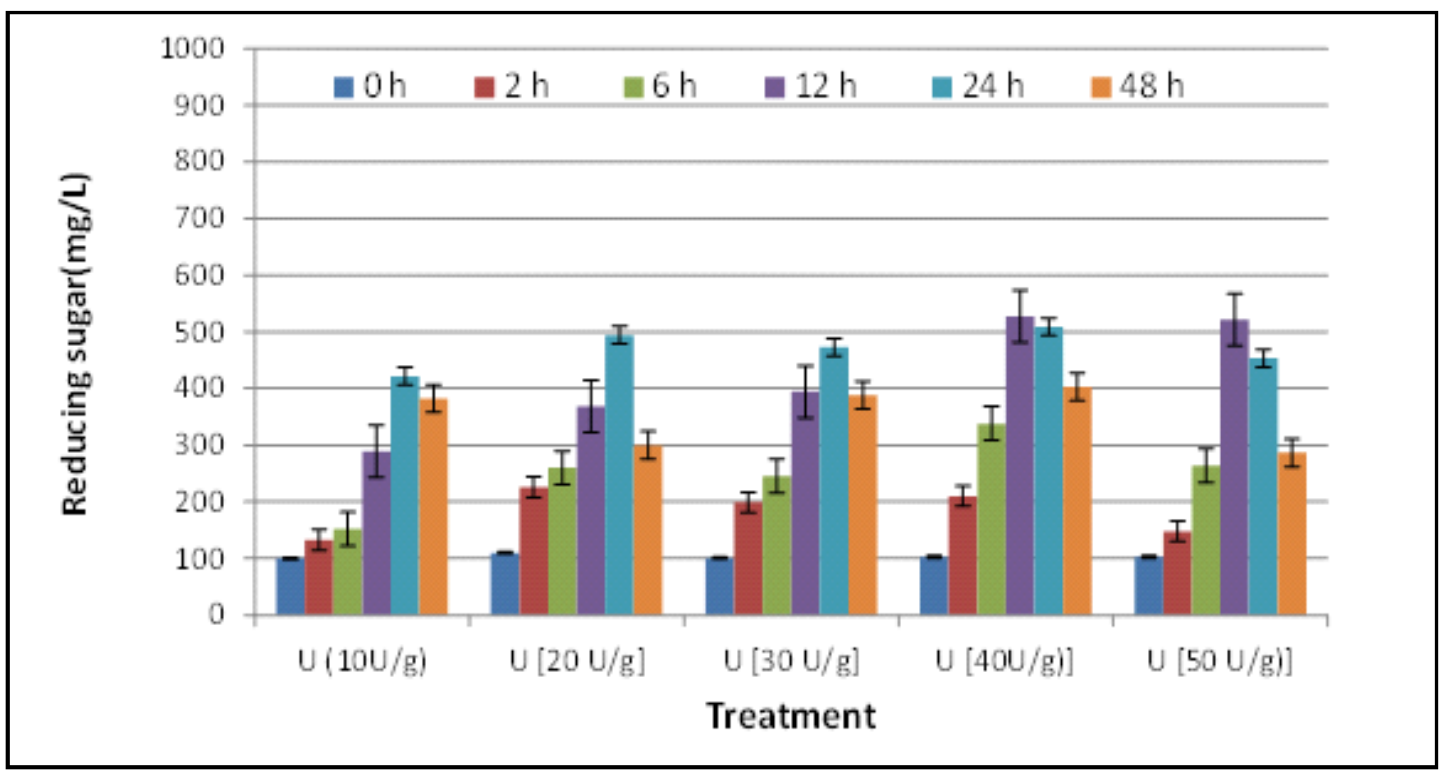

Figure 5. Saccharification of untreated $(U)$ seaweed solid waste using different cellulase concentration (10-50 $\mathrm{U} / \mathrm{g}$ agar waste) at $30^{\circ} \mathrm{C}$.

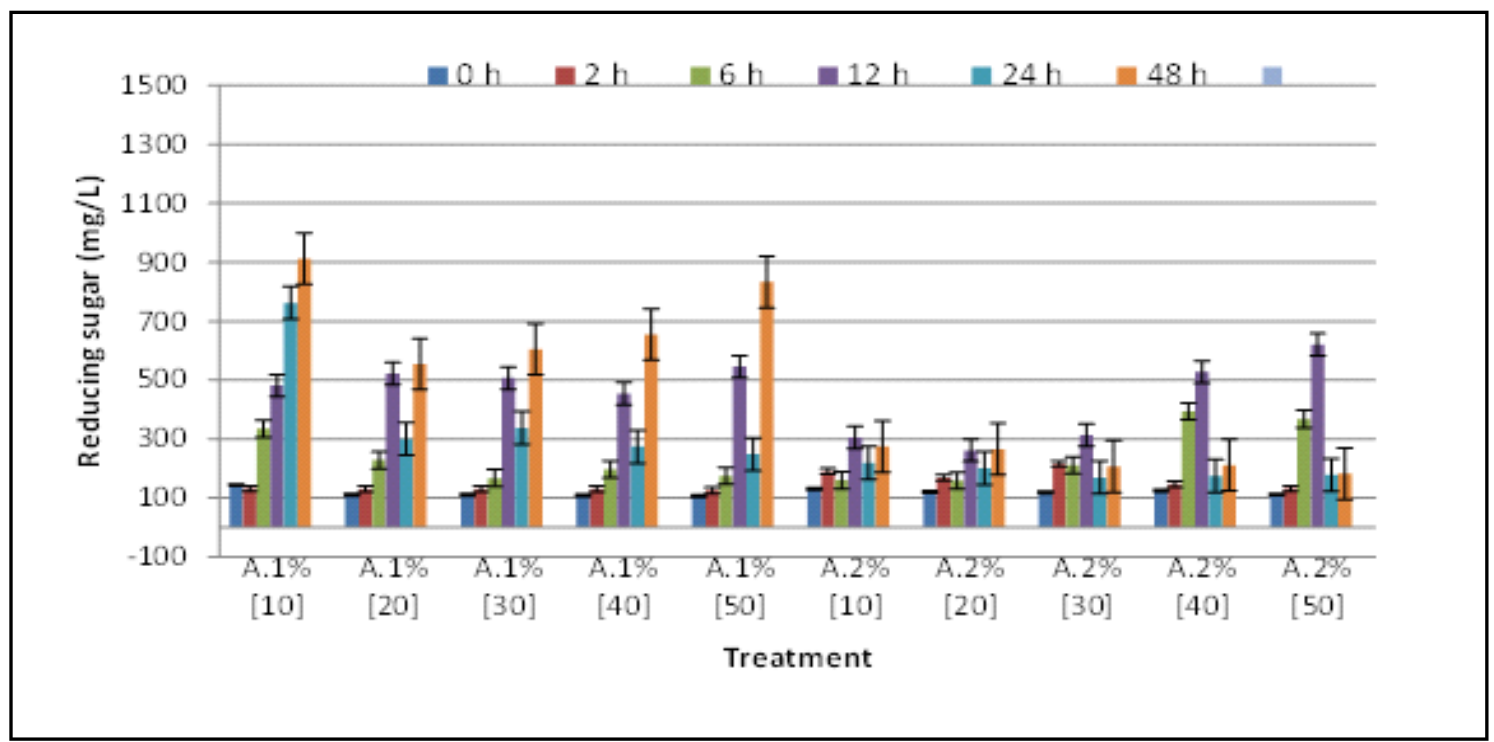

Figure 6. Saccharification of acid pretreated (A, at 1 and $2 \%)$ seaweed solid waste using various cellulase concentration (10-50 $\mathrm{U} / \mathrm{g}$ agar waste) at $30^{\circ} \mathrm{C}$ 
as shown in Figure 5. This is showed that the temperature of saccharification process plays an important role in the work of enzyme. The conversion rate of cellulose into sugar by enzymatic saccharification at $50^{\circ} \mathrm{C}$ reaching the maximum yield of approximately $60 \%$ lower than pretreatment of carrageenan waste by peracetic acid-ionic liquid which reported $77 \%$ of cellulose was converted into sugars (Uju et al., 2013).
Acid and base pretreated seaweed waste was treated with the same concentration of cellulase enzyme to produce more fermentable sugars as shown in Figures 9 and 10.

The challenge of the research that takes lignocellulosic materials for the generation of bioethanol is the low conversion of cellulose and hemicellulose, because of the presence of lignin. Various technologies for ethanol producing from

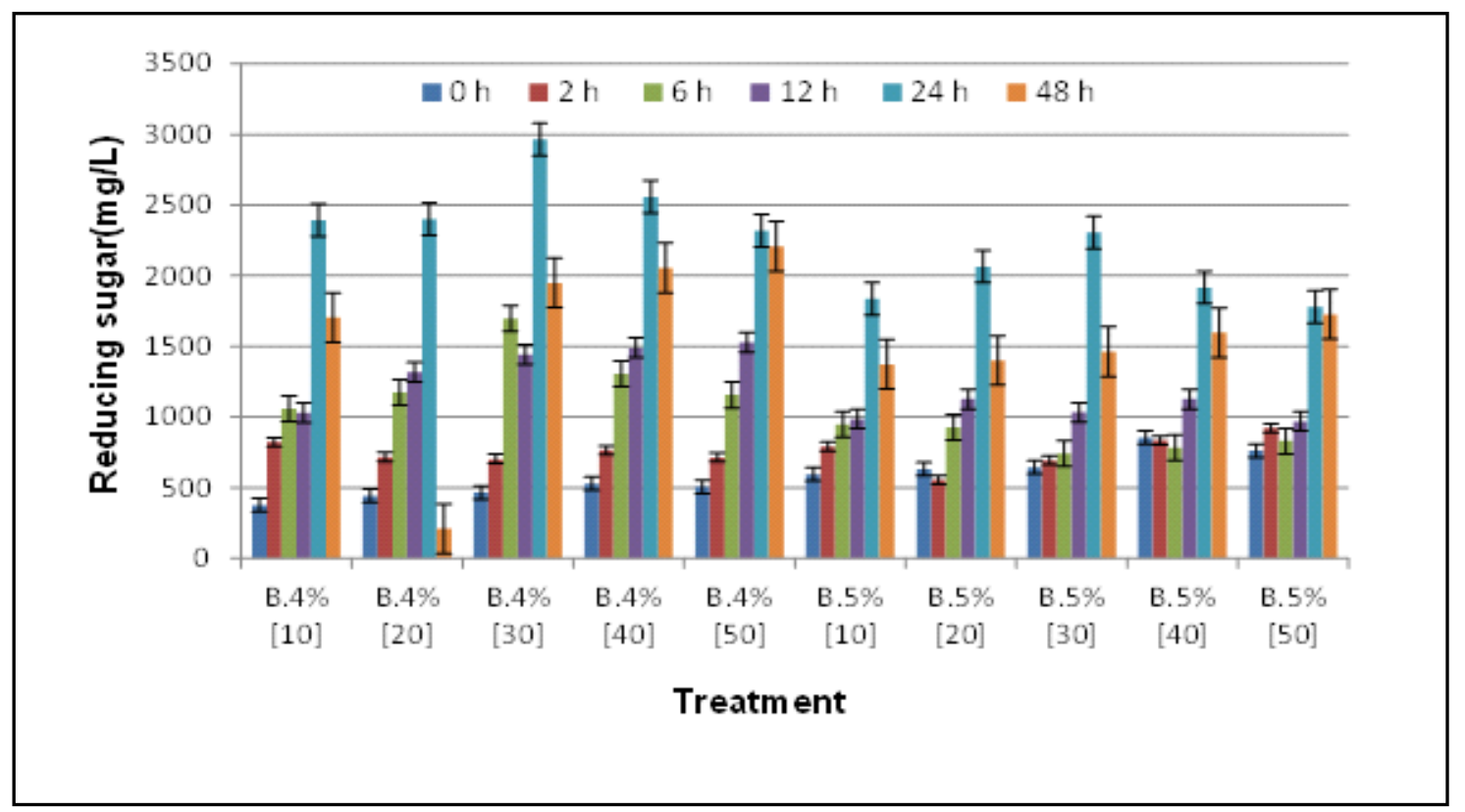

Figure 7. Saccharification of base pretreated (B, at 4 and $5 \%)$ seaweed solid waste using various cellulase concentration (10-50 U/g agar waste) at $30^{\circ} \mathrm{C}$.

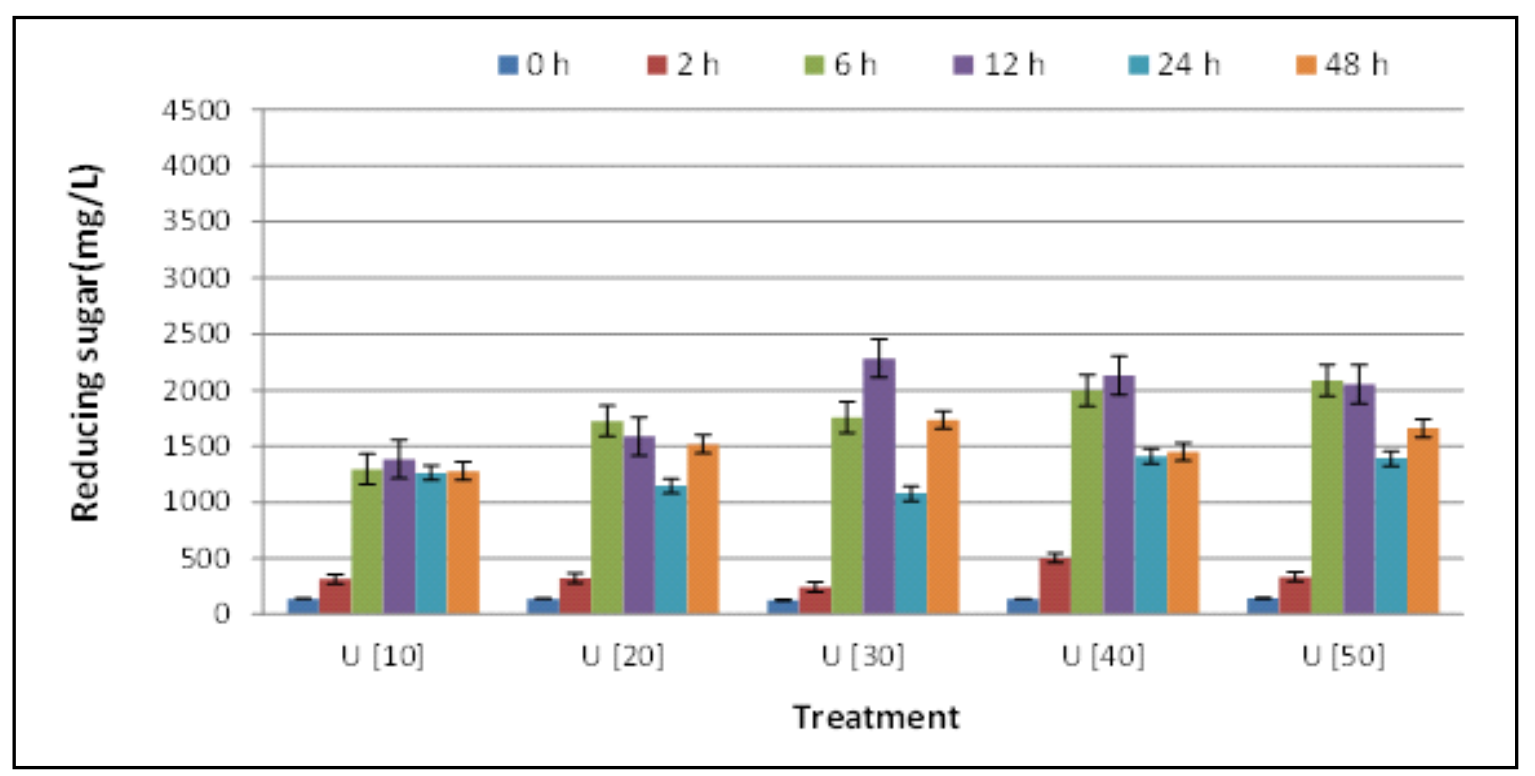

Figure 8. Saccharification of untreated $(U)$ seaweed solid waste using various cellulase concentration (10-50 $\mathrm{U} / \mathrm{g}$ agar waste) at $50^{\circ} \mathrm{C}$. 


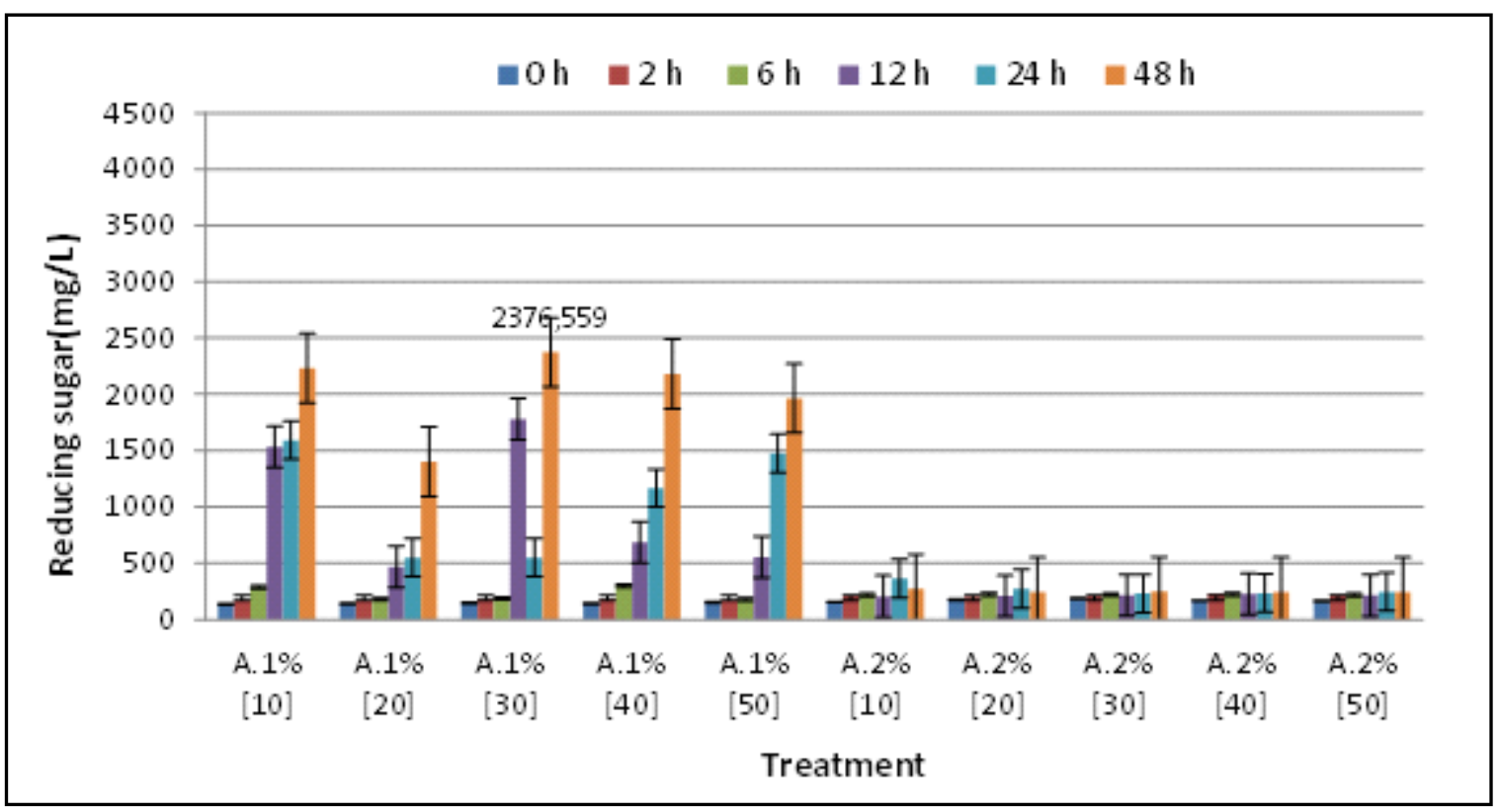

Figure 9. Saccharification of acid pretreated (A, at 1 and $2 \%$ ) seaweed solid waste using various cellulase concentration (10-50 $\mathrm{U} / \mathrm{g}$ agar waste) at $50^{\circ} \mathrm{C}$.

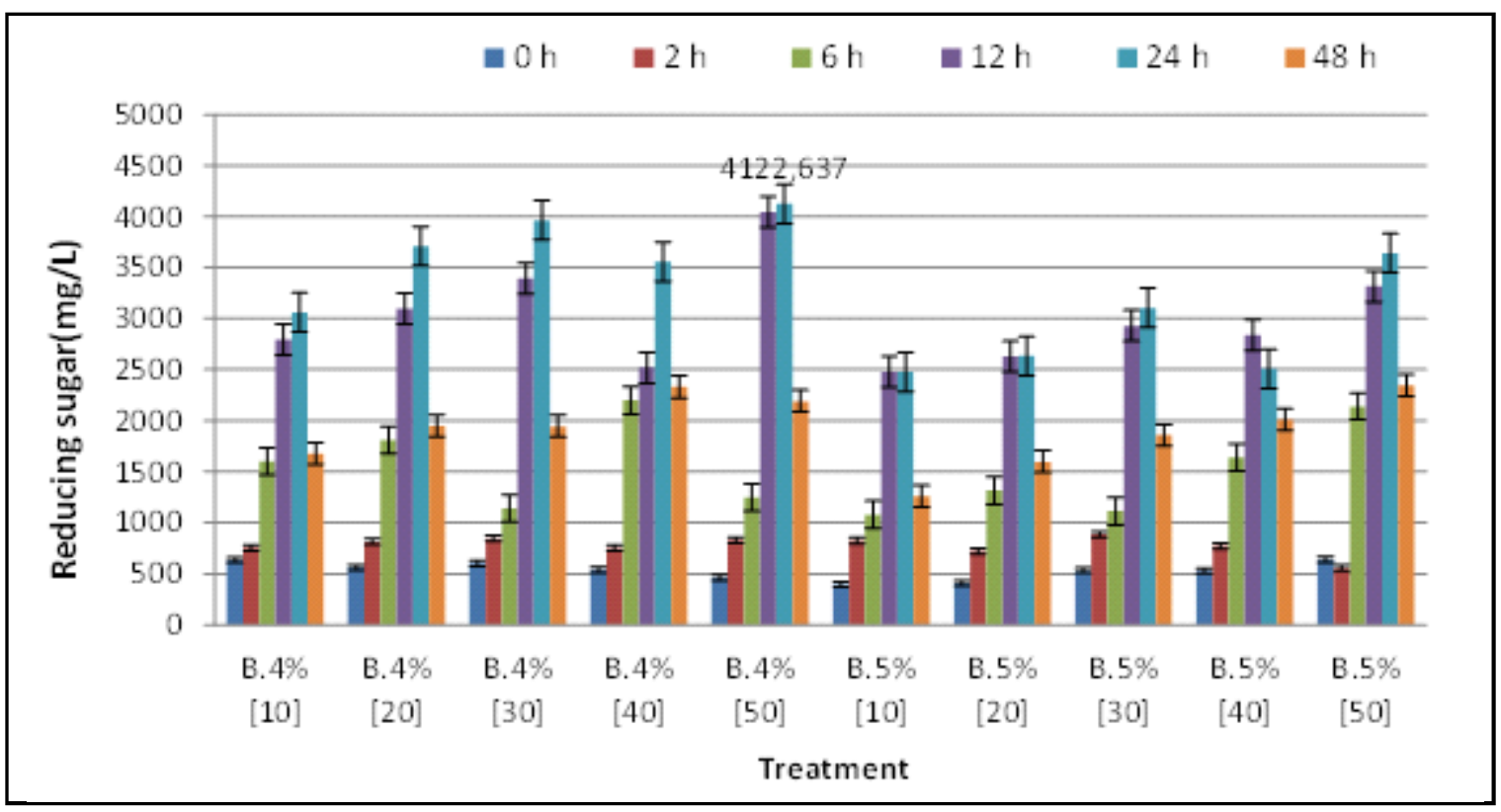

Figure 10. Saccharification of base pretreated (B, at 4 and $5 \%$ ) seaweed solid waste using various cellulase concentration (10-50 $\mathrm{U} / \mathrm{g}$ agar waste) at $50^{\circ} \mathrm{C}$.

lignocellulosic material conversion processes mainly focused on the pretreatment, especially the remotion of lignin, which improves the efficiency of cellulolytic enzymes (Fischer et al., 2008). The purpose of pretreatments is to break down the crystalline structure of cellulose, to hydrolyze much of the hemicellulose, and to solubilize or disrupt the lignin (Laser et al., 2002). The pretreatment methods are either physical or chemical, while some incorporate both effects. Numbers of pretreatments such as microbial pretreatment (Shi et al., 2009), dilute acid pretreatment (Saha et al., 2005), liquid hot water pretreatment (Perez et al., 2008), and alkaline wet oxidation (Klinke et al., 2002), have been used to improve the saccharification of the feedstocks. Of these methods, dilute acid pretreatment followed by enzymatic saccharification has been the most popular one (Gupta et al., 2009). The dilute acid can effectively 
solubilize hemicellulose into monomeric sugars and soluble oligomers, thus improving cellulose conversion (Sun \& Cheng, 2005). The investigation on the feasibility of bioethanol conversion from algae as a cellulose-based resource could be taken by using the same technique with terrestrial biomass.

Compared to other studies that using macroalga as source of cellulosic materials for bioethanol fermentation, this study showed that the application of $\mathrm{NaOH}$ followed by enzymatic hydrolysis were able to release $200 \mathrm{mg} / \mathrm{g}$ biomass, higher than acid pretreatment which release $118 \mathrm{mg} / \mathrm{g}$ biomass (Table 2). These results were lower than other studies which using whole macroalgae as raw materials. The highest reducing sugars was showed by Wu et al. (2014), producing $315 \mathrm{mg}$ reducing sugars on whole Gracillaria treated by acid and enzyme hydrolysis.

On the other hand, at more severe pretreatment conditions, the glucose released from cellulose may convert further to hydroxymethyl furfural (HMF) which is a kind of fermentation inhibitor. Steam pretreatment includes a risk on production of furfural, HMF, and soluble phenolic compounds, which can inhibit the ethanol fermentation. Strong acid pretreatment for the ethanol production is not attractive, because soluble lignin compounds are often inhibitors for the process

Table 2. Comparison of hydrolysis of seaweed/waste by various methods

\begin{tabular}{|c|c|c|c|}
\hline Materials & Hydrolysis Method & Sugar Released & References \\
\hline $\begin{array}{l}\text { Seaweed waste from } \\
\text { agar processing } \\
\text { (Pameungpeuk) }\end{array}$ & $\begin{array}{l}\text { Base/enzyme hydrolysis } \\
\text { - } 20 \% \text { biomass in } 4 \% \mathrm{NaOH}, 121^{\circ} \mathrm{C}, 30 \text { minutes } \\
\text { - } 50 \mathrm{U} \text { crude cellulose/g biomass, } 50{ }^{\circ} \mathrm{C}, 24 \mathrm{~h}\end{array}$ & $\begin{array}{l}\text { Reducing sugars: } \\
201 \mathrm{mg} / \mathrm{g} \text { biomass }\end{array}$ & Present study \\
\hline $\begin{array}{l}\text { Seaweed waste from } \\
\text { agar processing } \\
\text { (Pameungpeuk) }\end{array}$ & $\begin{array}{l}\text { Acid/enzyme hydrolysis } \\
\text { - } 20 \% \text { biomass in } 1 \% \mathrm{H}_{2} \mathrm{SO}_{4}, 121{ }^{\circ} \mathrm{C}, 30 \text { minutes } \\
\text { - } 30 \mathrm{U} \text { crude cellulose } / \mathrm{g} \text { biomass, } 50^{\circ} \mathrm{C}, 24 \mathrm{~h}\end{array}$ & $\begin{array}{l}\text { Reducing sugars: } \\
118 \mathrm{mg} / \mathrm{g} \text { biomass }\end{array}$ & Present study \\
\hline $\begin{array}{l}\text { Gracillaria } \\
\text { (whole biomass) }\end{array}$ & $\begin{array}{l}\text { Acid/enzyme hydrolysis } \\
\text { - } 20 \% \text { biomass in } 0.1 \mathrm{~N} \mathrm{H}_{2} \mathrm{SO}_{4} 121^{\circ} \mathrm{C} 1 \mathrm{~h} ; \\
\text { - } 0.01 \mathrm{~g} \text { cellulose } / \mathrm{g} \text { biomass } 50{ }^{\circ} \mathrm{C}, 100 \mathrm{rpm}, 6 \mathrm{~h}\end{array}$ & $\begin{array}{l}\text { Glucose : } 315 \\
\mathrm{mg} / \mathrm{g} \text { biomass }\end{array}$ & $\begin{array}{l}\text { Wu et al. } \\
(2014)\end{array}$ \\
\hline $\begin{array}{l}\text { Gracilaria sp. } \\
\text { (whole biomass) }\end{array}$ & $\begin{array}{l}\text { Acid hydrolysis: } 10 \% \text { biomass loading (w/v) in } 0.5 \mathrm{~N} \\
\mathrm{H}_{2} \mathrm{SO}_{4}, 121^{\circ} \mathrm{C}, 1.0 \mathrm{~h}\end{array}$ & $\begin{array}{l}\text { Glucose: } 2-50 \\
\mathrm{mg} / \mathrm{g} \text { biomass }\end{array}$ & $\begin{array}{l}\text { Wu et al. } \\
(2014)\end{array}$ \\
\hline $\begin{array}{l}\text { Gelidium amansii } \\
\text { (whole biomass) }\end{array}$ & $\begin{array}{l}\text { Continuous acid hydrolysis } 10 \% \text { biomass loading } \\
(\mathrm{w} / \mathrm{v}) \text { in } 2 \%(\mathrm{w} / \mathrm{v}) \mathrm{H}_{2} \mathrm{SO}_{4}, 150{ }^{\circ} \mathrm{C}, 3.0-3.5 \text { bar, flow rate } \\
40 \mathrm{~L} / \mathrm{h}, 4 \mathrm{~h}\end{array}$ & $\begin{array}{l}\text { Galactose: } 680 \\
\mathrm{mg} / \mathrm{g} \text { biomass } \\
\text { Glucose: } 130 \mathrm{~g} / \mathrm{g} \\
\text { biomass }\end{array}$ & $\begin{array}{l}\text { Park et al. } \\
\text { (2012) }\end{array}$ \\
\hline $\begin{array}{l}\text { Kappaphycus alvarezii } \\
\text { (whole biomass) }\end{array}$ & $\begin{array}{l}\text { Repeated acid hydrolysis } \\
5 \% \text { biomass loading (w/v) in } 0.9 \mathrm{~N} \mathrm{H} 2 \mathrm{SO} 4 \text {, } \\
100{ }^{\circ} \mathrm{C}, 1.0 \mathrm{~h}(5 \text { cycles, overall } 250 \mathrm{~g})\end{array}$ & $\begin{array}{l}\text { Reducing sugars: } \\
262 \mathrm{mg} / \mathrm{g} \text { biomass }\end{array}$ & $\begin{array}{l}\text { Khambhaty } \\
\text { et al., } 2012\end{array}$ \\
\hline $\begin{array}{l}\text { Kappaphycus alvarezii } \\
\text { (whole biomass) }\end{array}$ & $\begin{array}{l}\text { Acid hydrolysis: } 10 \% \text { biomass loading }(\mathrm{w} / \mathrm{v}) \text { in } 0.2 \% \\
(\mathrm{w} / \mathrm{v}) \mathrm{H}_{2} \mathrm{SO}_{4}, 130{ }^{\circ} \mathrm{C}, 15 \mathrm{~min}\end{array}$ & $\begin{array}{l}\text { Reducing sugars: } \\
305 \mathrm{mg} / \mathrm{g} \text { biomass } \\
\text { Galactose: } 256 \\
\mathrm{mg} / \mathrm{g} \text { biomass }\end{array}$ & $\begin{array}{l}\text { Meinita et al. } \\
(2012)\end{array}$ \\
\hline $\begin{array}{l}\text { Brown seaweed } \\
\text { Laminaria japonica } \\
\text { (whole biomass) }\end{array}$ & $\begin{array}{l}\text { Acid/enzyme hydrolysis } 18 \% \text { biomass loading }(\mathrm{w} / \mathrm{v}) \text { in } \\
0.1 \mathrm{~N} \mathrm{HCl}, 121 \text { _C, } 15 \mathrm{~min} \\
\text { Viscozyme_L /Celluclast_ } 1.5 \mathrm{~L} ; 1: 11 \mathrm{ml} \text { in } 100 \mathrm{~g} \text { dry } \\
\text { biomass } 50 \_\mathrm{C}, 150 \mathrm{rpm}, \mathrm{pH} 5.5,24 \mathrm{~h}\end{array}$ & $\begin{array}{l}\text { Glucose: } 69.8 \\
\mathrm{mg} / \mathrm{g} \text { biomass } \\
\text { Maninitol: } 305 \\
\mathrm{mg} / \mathrm{g} \text { biomass }\end{array}$ & $\begin{array}{l}\text { Kim et al. } \\
(2011)\end{array}$ \\
\hline Sargassum spp. & $\begin{array}{l}\text { Acid/enzyme hydrolysis: } \\
-10 \% \text { biomass loading }(\mathrm{w} / \mathrm{v}) \text { in } 4 \%(\mathrm{w} / \mathrm{v}) \mathrm{H}_{2} \mathrm{SO}_{4}, \\
115^{\circ} \mathrm{C}, 1.5 \mathrm{~h} \\
-250 \mathrm{CBU} \text { cellobiase } / \mathrm{g} \text { biomass } 50{ }^{\circ} \mathrm{C}, 100 \mathrm{rpm}, \mathrm{pH} \\
4.8+10 \mathrm{FPU} \text { cellulase } / g \text { biomass } 96 \mathrm{~h}\end{array}$ & $\begin{array}{l}\text { Reducing sugars: } \\
120 \mathrm{mg} / \mathrm{g} \text { biomass } \\
\text { Glucose: } 40 \mathrm{mg} / \mathrm{g} \\
\text { biomass }\end{array}$ & $\begin{array}{l}\text { Borines et al., } \\
2013\end{array}$ \\
\hline
\end{tabular}


(Hendriks and Zeeman, 2009). In this research, since the pretreatment of seaweed waste was performed at lower temperature $\left(121^{\circ} \mathrm{C}\right)$ with low-concentration sulfuric acid $(0.5-2 \%)$, there are little inhibitors formed in the hydrolysates. The differences of chemical composition and spatial structure between land-derived and marine-derived biomassmight explain why little inhibitors are produced from acid pretreatment.

\section{Conclusion}

The dilute acid and base for treatment of seaweed solid waste can be used to improve the digestibility of seaweed waste for the production of cellulose enzyme. $4 \% \mathrm{NaOH}$ pretreatment effectively remove $90 \%$ lignin and maintaining cellulose. The susceptibility of pretreated solid agar waste to enzymatic bioconversion was increased as shown in the XRD analysis, $1 \% \mathrm{H}_{2} \mathrm{SO}_{4}$ and $4 \% \mathrm{NaOH}$ pretreatment converting crystalline cellulose into amorphous form. The results of SEM on solid agar waste strengthen the finding that the cellulose structure was more susceptible to enzyme action after $1 \% \mathrm{H}_{2} \mathrm{SO}_{4}$ and $4 \% \mathrm{NaOH}$. Saccharification at $50{ }^{\circ} \mathrm{C}$ produced more reducing sugars (Conversion ratio: $206 \mathrm{mg} / \mathrm{g}$ biomass) than $30^{\circ} \mathrm{C}$ (conversion ratio: $118 \mathrm{mg} / \mathrm{g}$ biomass). The highest concentration of fermentable sugars were reached at $50^{\circ} \mathrm{C}$ for 24 hours of saccharification. The conversion rate of cellulose into sugar was approximately $60 \%$ at those conditions. The results of the experiment were expected to contribute in the process development of bioconversion of lignocellulosic materials into renewable energy sources.

\section{References}

Adams, J.M., Gallagher, J.A., \& Donnison, I.S. (2009). Fermentation study on Saccharina latissima for bioethanol production considering variable pretreatments. J. Appl.Phycol. 21, 569-574.

Balat M., \& Balat H. (2009). Recent trends in global production and utilization of bio-ethanol fuel. Appl Energ. 86(11):2273-82.

Borines, M.G., de Leon, R.L., \& Cuello, J.L. (2013). Bioethanol production from the macroalgae Sargassum spp. Bioresour. Technol. 138, 22-29.

Cara C, Ruiz E, Oliva JM, Sáez F., \& Castro E. (2008). Conversion of olive tree biomass into fermentable sugars by dilute acid pretreatment and enzymatic sacchariûcation. Bioresour Technol. 99:1869-76.

del Campo I, Alegría I, Zazpe M, Echeverría M., \& Echeverría I. (2006). Diluted acid hydrolysis pretreatment of agri-food wastes for bioethanol production. Ind. Crop Prod. 24:214-21.

Fischer CR, Klein-Marcuschamer D., \& Stephanopoulos G. (2008). Selection and optimization of microbial hosts for biofuels production. Metab Eng.10(6):295304.

Ge, L., Wang, P., \& Mou, H. (2011). Study on saccharification techniques of seaweedwastes for the transformation of ethanol. Renew. Energy 36, 8489.

Gupta R, Sharma K.K., \& Kuhad R.C. (2009). Separate hydrolysis and fermentation (SHF) of Prosopis juliûora, a woody substrate, for the production of cellulosic ethanol by Saccharomyces cerevisiae and Pichia stipitis-NCIM 3498. Bioresour Technol. 100(3):1214-20.

Hendriks, ATWM., \& Zeeman, G. (2009). Pretreatments to enhance the digestibility of lignocellulosic biomass. Bioresour Technol. 100:10-18.

Horn, S.J., Aasen, I.M., \& Østgaard, K., (2000). Ethanol production from seaweed extract. J. Ind. Microbiol. Biotechnol. 25, 249-254.

Khambhaty, Y., Mody, K., Gandhi, M.R., Thampy, S., Maiti, P., Brahmbhatt, H.,Eswaran, K., \& Ghosh, E.K. (2012). Kappaphycus alvarezii as a source of bioethanol. Bioresour. Technol. 103, 180-185.

Kim, N.J., Li, H., Jung, K., Chang, H.N., \& Lee, P.C. (2011). Ethanol production from marine algal hydrolysates using Escherichia coli KO11. Bioresour. Technol. 102, 7466- 7469.

Klinke HB, Ahring BK, Schmidt AS., \&Thomsen AB. (2002). Characterization of degradation products from alkaline wet oxidation of wheat straw. Bioresour Technol. 82:15-26.

Kumar, S., R. Gupta., G. Kumar., D. Sahoo and R.C., \& Kuhad. (2013). Bioethanol production from Gracillaria verrucosa, a red alga, in a biorefinery approach. Bioresour. Technol. 135:150-156.

Laser M., Schulman D., Allen SG., Lichwa J., Antal Jr MJ., \& Lynd L.R. (2002). A comparison of liquid hot water and steam pretreatments of sugar cane bagasse for bioconversion to ethanol. Bioresour Technol. 81:3344.

Meinita, M.D.N., Hong, Y., \& Jeong, G. (2011). Comparison of sulfuric acid andhydrochloric acids as catalysts in hydrolysis of Kappaphycus alvarezii(cottonii). Bioprocess Biosyst. Eng. 35 (1-2), 123-128.

Meinita, M.D.N., Kang, J.Y., Jeong, G.T., Koo, H.M., Park, S.M., \& Hong, Y.K. (2012). Bioethanol production from the acid hydrolysate of the carrageenophyte Kappaphycus alvarezii (cottonii). J. Appl. Phycol. 24, 857-862.

Özdemir ED., Härdtlein M., \& Eltrop L. (2009). Land substitution effects of biofuel side products and implications on the land area requirement for EU 2020 biofuel targets. Energ Policy. 37:2986-96.

Park, J.H., Hong, J.Y., Jang, H.C., Oh, S.G., Kim, S.H., Yoon, J.Y., \& Kim, Y.J. (2012). Use of Gelidim amansii as a promising resource for bioethanol: a practical approach for continuous dilute-acid hydrolysis and fermentation. Bioresour. Technol. 108: 83-88.

Pérez J.A., Ballesteros I., Ballesteros M., Sáez F., Negro MJ., \& Manzanares P. (2008). Optimizing liquid hot 
water pretreatment conditions to enhance sugar recovery from wheat straw for fuel-ethanol production. Fuel. 87:3640-7.

Petersen MØ, Larsen J., \&Thomsen MH. (2009). Optimization of hydrothermal pretreatment of wheat straw for production of bioethanol at low water consumption without addition of chemicals. Biomass Bioenerg. 33:834-40.

Saha BC, Iten L.B., Cotta MA., \& Wu Y.V. (2005). Dilute acid pretreatment, enzymatic saccharification and fermentation of wheat straw to ethanol. Process Biochem. 40:3693-700.

Sahoo, D., Elangbam, G., \& Devi, S.S. (2012). Using algae for carbon dioxide capture and bio- fuel production to combat climate change. Phykos 42, 32-38.

Shi J, Sharma-Shivappa RR, Chinn M, \& Howell N. (2009). Effect of microbial pretreatment on enzymatic hydrolysis and fermentation of cotton stalks for ethanol production. Biomass Bioenerg. 33(1):88-96.

Sun Y., \& Cheng J.J. (2005). Dilute acid pretreatment of rye straw and bermudagrass for ethanol production. Bioresour Technol. 96:1599-606.
Suurs RAA., \& Hekkert M.P. (2009). Competition between first and second generation technologies: lessons from the formation of a biofuels innovation system in The Netherlands. Energy. 34:669-79.

Yeon, J.-H., Lee, S.-E., Choi, W.Y., Kang, D.H., Lee, H.-Y., \& Jung, K.H. (2011). Repeatedbatchoperation of surface-aerated fermentor for bioethanol production fromthe hydrolysate of seaweed Sargassum sagamianum. J. Microbiol. Biotechnol. 21(3), 323331.

Yoon, J.-J., Kim, Y.J., Kim, S.H., Ryu, H.J., Choi, J.Y., Kim, G.S., \& Shin, M.K. (2010).Production of polysaccharides and corresponding sugars from red seaweed. Adv. Mater. Res. 93-94, 463-466.

Uju., K. Abe., N. Uemura., T.Oshima., M. Goto., \& N. kamiya. (2013). Peracetic acid-iocic liquid pretreatment to enhance enzymatic saccharification of lignocellulosic biomass. Bioresour. Technol. 138C:87-94.

Wu, F.C., J. Y. Wu., Y.J.Liao., M.Y. Wang., \& I.L. Shih. (2014). Sequential acid and enzymatic hydrolysis in situ and bioethanol production from Gracillaria biomass. Bioresour. Technol. 156:123-131. 